\title{
Participatory Constitution-Building in Nepal
}

\section{- A Comparison of the 2008-2012 and the 2013-2015 Process}

\author{
Abrak Saati ${ }^{1}$ \\ ${ }^{1}$ Department of Political Science, Umeå University, Sweden \\ Correspondence: Abrak Saati, Department of Political Science, Umeå University, Sweden. Tel: 90-786-6174. \\ E-mail: abrak.saati@umu.se
}

Received: May 31, $2017 \quad$ Accepted: July 1, $2017 \quad$ Online Published: August 16, 2017

doi:10.5539/jpl.v10n4p29

URL: https://doi.org/10.5539/jpl.v10n4p29

\begin{abstract}
Participatory constitution-building is a trend that appears to be here to stay; particularly when new constitutions are drafted in the aftermath of war or during transitions from authoritarian to democratic rule. Anticipations as to what the involvement of the public will achieve are several, and scholars are only recently starting to systematically investigate whether or not these expectations find empirical support. Previous research has shown that public participation in the making of the constitution can have certain positive effects at an individual level of analysis, but that the actions of political elites during constitutional negotiations might affect outcomes at a macro level of analysis more than what has hitherto be acknowledged in this strand of research. Nepal is one of the most recent cases of participatory constitution-building, and the country carried out not only one, but two, such processes within a time period of only seven years. The first resulted in failure as a draft constitution was never finalized; the other in success with the adoption of a constitution in 2015. This article takes an interest in exploring and comparing these two separate processes as regards the extent of public participation vis-à-vis political elite negotiations and bargaining behind closed doors. The article finds that what primarily sets the two processes apart, is how broad based public participation and secluded elite negotiations were sequenced. In light of other empirical examples, the article also discusses if elite bargains ought to be struck before the general public are invited to participate.
\end{abstract}

Keywords: Nepal, constitution-building, public participation, political elite bargaining, sequencing

\section{Introduction}

Constitution-building, to considerably alter or to re-write the founding laws in their entirety, has become an integral part of many transitional processes around the world; especially when the transition in question is from war to peace or from authoritarian to democratic rule (Widner, 2008; Elster, 1995: 370-371). Examples in which post-conflict or post-authoritarian constitution-building has taken place include East Timor, Rwanda, South Africa, Albania, Kenya, Afghanistan, Iraq, Colombia, Tunisia and Nepal, to name only but a few. To be sure, constitution-building is one of the most salient aspects of transitional processes, and the reason is quite straightforward; the constitution stipulates the rules of the political game, and in post-war and post-authoritarian contexts it is therefore essential that key stakeholders, i.e. political elites from different political factions, get at least some of their demands met when these rules are made, if democracy is to have a viable chance to consolidate and stability prevail (Rustow, 1970; Samuels, 2006; Benomar, 2003). However, in addition to these, so to speak, evident stakeholders that undeniably need to be included in the making of the new political order, we have from the onset of the 1990s and the ushering in of the peacebuilding era witnessed how this understanding of who the legitimate "constitution-makers" are, dramatically expand to now also include ordinary citizens of countries (Ghai \& Galli, 2006).

Today, participatory constitution-building has become a new norm in post-conflict contexts and in contexts of transitions from authoritarianism (Saati, 2017a; Hart, 2010). Scholars in this field of research, and peacebuilding practitioners alike, have placed high hopes on what public participation in constitution-building processes is to achieve. Anticipations concern an increase of democracy at a macro level of analysis (Saati, 2015, Banks, 2007, Banks, 2008), reconciliation between former adversaries of war (Ghai \& Galli, 2006; Hart, 2003; Samuels, 2006: 5-6), an educated citizenry aware of their constitutional rights (Ghai \& Galli, 2006: 14; Samuels, 2006: 8), and a 
constitution perceived as legitimate by the population due to their participation in the process of its making (Hart, 2003; Samuels, 2009). Though participatory constitution-building has the potential to give rise to benefits, particularly at an individual level of analysis (Moehler, 2008), considerable scholarly attention is yet to be devoted to systematically investigating if, and if so how, participatory constitution-building has indeed brought about these anticipated effects in different empirical cases. Recent work has shown that it is, in fact, difficult to attribute participation to specific outcomes, and that as far as democracy enhancement at the macro level of analysis is concerned, there is no direct relationship between the two, nor is public participation a panacea that will solve many of the challenges faced by, particularly, post-conflict states (Saati, 2015). Rather, it appears that the actions of political elites during constitutional negotiations matters much more than what has hitherto been acknowledged in this strand of research (Saati, 2015; Cheeseman \& Tendi, 2010), and that elite negotiations perhaps matter even more than public participation in terms of paving the way to a consolidated democracy. The point of departure in the present article is, however, that these two poles, that on the surface may appear as conflicting ends on a scale, i.e. public participation and political elite negotiations, are both important in the context of constitution-building, and that scholars and peacebuilding practitioners need to properly understand and analyze how, and during which stages, the public on the one hand and the political elites on the other hand, can and should be involved in the making of the new constitution. Building on the findings of a recent study (Saati, 2017b) in which tentative conclusions relating to the Tunisian and South African participatory constitution-building processes are discussed, I argue that a case can be made for the careful sequencing of events in constitution-building processes, particularly when it comes to when the general public may be included, so that a constitution can de facto be produced, and democratization with a long perspective in mind, facilitated.

Nepal is one of the most recent cases of post-conflict constitution-building in which the public played an important role in terms of directly participating in the process of its making. Following a decade long civil war, a Comprehensive Peace Accord (CPA) was finally signed between the government of Nepal and Moist insurgents in late 2006, marking the end of hostilities, the abolishment of monarchy rule and the transition to political democracy (Khanal, 2014: 1). An essential component of the CPA was the election of a Constituent Assembly and the drafting of a new constitution (Khanal, 2014: 1). As the Constituent Assembly was not able to produce a constitution within the timeframe of its mandate, a second Constituent Assembly was elected in 2013 to finalize the process.

The purpose of this article is two-fold. The first is to understand how the public participation phase of the two separate constitution-building processes in Nepal (2008-2012, and 2013-2015) played out in terms of extent of influence granted to the general public. Was the Nepalese populace given the opportunity to genuinely participate, or were they rather engaging without any actual influence on the final document? The second purpose of this paper is to understand whether, and if so, to what extent, political elite negotiations, compromises and bargaining had an impact as regards producing a final document. As stated in the introductory note above, participatory constitution-building has developed into a new norm, particularly in post-conflict contexts. With a historic perspective, however, this is a new occurrence, and scholars are now in the process of systematically exploring different empirical cases of participatory constitution-building in order to detect patterns, understand processes design options related to different outcomes, etc. By focusing on Nepal, this paper will increase our knowledge about the specifics of this particular case, but will also lay another piece to a larger research puzzle concerning participatory constitution-building during times of transition.

This article is organized in the following way: In the next section, I discuss what is meant by public participation in constitution-building processes and how we can go about assessing how participatory the two separate Nepalese constitution-building processes really were. This is followed by a theoretical section that focuses on analyzing the role of political elites in constitution-building processes during times of transitions, from war to peace, or from authoritarian to democratic rule. Thereafter, the empirical section of the paper ensues in which the participatory aspects of the first Nepalese constitution-building process (2008-2012) are compared with the participatory aspects of the second process (2013-2015). In this analysis, the role of political elites during both of these processes are also discussed. In the final section of the paper, conclusions are elaborated.

\section{Public Participation in Constitution-Building}

Though participatory constitution-building in post-conflict contexts and in contexts of transition from authoritarian rule is a fast establishing norm, conveyed and enforced by a number of influential international organizations, such as the United Nations Department of Political Affairs, the United States Institute of Peace and International IDEA (Saati, 2017a), what is really meant by "participation" is still, oddly enough, vague. There is undeniably an interest in providing opportunities for the general public to get involved in the making of their founding laws, but the question remains as to what it actually means to "participate"? Though there are 
valuable scholarly contributions that address what participation in political decision-making in general entails (Pateman, 1970; Arnstein, 1969), the term as such has suffered from under conceptualization when it comes to what it implies in the specific context of constitution-building. This has, in turn, made the concept of participation difficult to operationalize in a manner that allows for its qualitative assessment. Instead, it has become convenient to understand and measure "participation" in quantitative terms. This has implied that the extent to which a constitution-building process has been understood to be more or less participatory, has been determined primarily by how many individuals that have been involved in the process; how many constitutional submissions that formal constitution-building bodies have received from members of the general public; how many meetings/conferences/work-shops various constitutional commissions have organized with the public, etc. (see e.g. Ebrahim \& Miller, 2010: 136; Tripp, 2010: 163; Fox et al., 2010: 471-472). Though quantitative measures like these can be important in the sense that they reveal a part of the story, they also leave much untold.

I have in previous studies (Saati, 2015; Saati, 2016) argued that participation in all types of political decision-making must translate into, at least, some amount of influence for those who are participating if we are to use the term "participation" in a manner that captures the core essence of the term. Certainly, this is not a controversial argument. Quite the contrary. That participation ought to imply actual influence over decisions being made, has been theorized and discussed by some of the most prominent contemporary deliberative and participatory theorists in the field of political science (Pateman, 1970; Arnstein, 1969). In the context of constitution-building, which is in its very essence a political undertaking and not just a legal exercise, this implies that public participation, if one is really to refer to it as such, must translate into influence over the content of the constitutional document, alternatively, influence over the adoption of the document in its entirety, via referendum. If participation, on the other hand, does not translate into influence, the people have - to put it crudely - only participated in the act of participation.

To date, quite a number of constitution-building processes in post-conflict states and in states transitioning from authoritarian rule have included popular participation, Nepal only being one of the most recent examples. The extent to which the respective populations of the countries in which participatory constitution-building has been undertaken, have been allowed to exert influence over the content of the constitution, however, differs vastly and cannot be captured merely by counting the number of constitutional submissions that individuals have formulated, the number of town hall meetings that have been arranged with the public, and other things of this nature. The issue that must be addressed at this point is, of course, how one determines the extent of influence that the public have been allowed to exercise through their participation. I turn to this issue next.

In an ideal research reality, there would be a database in which information concerning all constitutional submissions received from the public during a specific constitution-building process were gathered and systematically organized. The same database would also be able to provide us with information about which one of these submissions, and how many percent of these submissions, actually made their way into the final constitutional draft. Such a database would fulfill both quantitative as well as qualitative objectives, and would indeed serve this field of research well. However, as there is yet no such database for scholars to consult, other measures must be taken in order to try and determine the extent of popular influence on the document.

In order to address this issue, I have in earlier work (Saati, 2015: 18-45) devoted attention to developing an analytical framework for distinguishing different types of participatory constitution-building, depending on the amount of influence that the general public have been allowed to exert through their participation. Due to space limitations, this is not the place to elaborate the theoretical underpinnings of this analytical framework in full, suffice is to say that there are four significant factors, related to any participatory constitution-building process, that ought to be analyzed in order to uncover the extent of influence participants have been allowed to exercise. These four factors are: i) who the initiators of the process have been. Indeed, those who initiate the process, regardless of them being international actors or different types of domestic actors, have the possibility to shape the process in a manner that allows more/less influence for the general public; ii) how the forms of communication with the public have been constructed. The question to be answered is whether the general public have merely been passive participants and recipients of information, or if they have been presented with actual avenues for providing input and feedback to the constitutional drafters; iii) the degree of inclusion. To be sure, not all participatory constitution-building process are actually fully inclusive in the sense that everyone is welcome to participate. Hence, the issue under consideration is; are any groups/political affiliations banned from participating?; iv) and lastly, the question of final authority over the adoption of the constitution. In whose hands does ultimate authority lie? Is final authority vested in the hands of the executive, indirectly in the hands of the general public through a constitutional assembly, or directly in the hands of the public through a referendum?

When one takes all of these four factors into consideration, a qualitative assessment can be made that gives a 
fairly good indication as to the extent of influence the general public in a given constitution-building process have been granted. This assessment, in turn, makes it possible to categorize cases as having been more or less participatory (for a comparison of 20 different empirical cases, please be referred to Saati, 2015: 88-91). When turning to the empirical investigation of the two separate Nepalese constitution-building processes, these factors will be useful for purposes of analyzing the participatory aspects of these processes and to determine the extent to which they were actually participatory. For now, we will direct our attention to the role of political elites in constitution-building during times of transition. This is the focus of the following section.

\section{Political Elites in Constitution-Building Processes during Times of Transition}

Though participatory constitution-building in post-conflict states and in states in transition from authoritarian rule is a trend that appears to be here to stay, the limitations of what participation can achieve in and by itself are increasingly being recognized (Landau, 2012; Saati, 2015). It appears that, without some baseline agreement amongst political elites concerning fundamental constitutional principles, there is not much that public participation in the making of the constitution can accomplish (Saati, 2017b). One must bear in mind that constitution-building processes, particularly in the aftermath of war, are conducted in contexts where political institutions are, by and large, nonexistent, and in contexts where interpersonal trust is low, at best. One of the central aims of any constitution is to remedy the first of these - i.e. to create political institutions and to bring clarity in regards to how they are to function. The hopes of proponents of participatory constitution-building, in addition to this goal, is that public participation in the process will contribute to address the second one - i.e. that social capital will be reinforced as a consequence of people coming together and jointly formulating the constitution (Moehler, 2008). Though this is an admirable aspiration, much less is known about how this prediction plays out in reality. Nevertheless, the main question when it comes to constitution-building in times of transition, as amply put by Landau (2012: 925), is to figure out "how to structure constitution-making processes so as to enhance the prospects that the resulting regime will be a stable and competitive democracy". It is indeed in addressing this very issue that the role of political elites from opposing factions becomes central. Two diametrically opposing paths appear possible. Either, political elites can chose to use - or perhaps more accurately, misuse - the constitution-building process to advance their own short-term interests without any regard as to the wellbeing of the society at large (Landau, 2012: 926). Or, they can chose to utilize the constitution-building process in a manner that benefits not only themselves, but the whole of society with a long-term perspective in mind. Now, the inevitable question is, why would political elites opt for the second alternative rather than the first? According to Larry Diamond (Diamond et al., 2014: 91), political elites are prone to support democratic political institutions so long as they believe that democracy benefits their own self-interests. If this self-interest coincides with that of the country at a societal level; all the better, since a win-win situation occurs. To achieve this win-win situation, it is of crucial importance that political elites in states that find themselves in transition, from war to peace or from authoritarian to democratic rule, make sure that all major stakeholders get at least some of their demands met when the new rules of the political game are constructed so that no one is left emptyhanded in this game of bargaining (Rustow, 1970). In the context of constitution-building, this requires political elites who have a considerable amount of level-headiness; who have the ability not to act on sudden and fervent impulses; who are able to make decisions based on rational and impartial arguments, and who are able to look beyond the horizon of their own term in office and realize that they are, in effect, legislating for future generations (Elster, 1995: 383). This required form of level-headiness, in turn, appears to be facilitated by deliberations made in secrecy, i.e. far away from the public eye, and certainly without the involvement of the general public. The gist of Elster's argument, from two decades ago, is worth quoting at length:

"...secrecy tends to improve the quality of whatever discussion does take place because it allows framers to change their mind when persuaded of the truth of an opponent's view. Conversely, while public debate drives out any appearance of bargaining, it also encourages stubbornness, overbidding, and grandstanding in ways that are incompatible with genuine discussion. Rather than fostering transformation of preferences, the public setting encourages their misrepresentation".

(Elster, 1995: 388)

Seeing that constitution-building, paradoxically, usually takes place during circumstances that do not favor good constitution-making, i.e. during turbulent times, all measures that can be taken to make this exercise as non-conflicting as possible are advisable. This ought to include careful thought as to the issue of public participation during the drafting of the constitution. This is not to say that the public must be precluded from 
participating entirely, but that their participation should perhaps be sequenced to phases of the process when it is more conducive. Based on the quote by Elster, maybe it is more sensible to include the public once political elites have, in secrecy, agreed on some of the most sensitive constitutional issues. How the participation of the public in both of the Nepalese constitution-building processes played out, is the focus of the empirical section of this article, which ensues below.

\section{The Nepalese Constitution-Building Process of 2008-2012}

As stated in the introductory note, a Comprehensive Peace Accord was signed between Maoist insurgents and the government of Nepal in 2006, in which it was agreed that the country would elect a Constituent Assembly for the subsequent drafting of a new constitution. Hence, as far as the initiators of the constitution-building process are concerned, domestic actors who had been on opposing sides in the decade long war, mutually agreed that it was necessary for Nepal to write a new political roadmap (Khanal, 2014). Interestingly, for the first time in Nepal's constitutional history, it was also agreed that the making of the constitution would be participatory, i.e. that the general public in Nepal would be invited to make their opinions heard as to what they perceived to be important to include in the new constitution (Khanal, 2014). Indeed, in the making of Nepal's six previous constitutions $(1948,1951,1959,1962,1990$ and 2007) citizens had been entirely precluded from participating (Shakya, 2014: 89).

Before a Constituent Assembly could be elected, however, an interim constitution that would outline the parameters of the assembly's work had to be adopted. To this end, an interim constitution was promulgated in early 2007. This document, in turn, anticipated a number of extensive transformations for Nepal. Among others; the monarchy was to be abolished and a republican system of government installed in its place, the unitary state would have to give way to a federal state structure, civil conflict would be replaced by peaceful politics, and inclusive democracy would replace non-inclusive state mechanisms that had, for a long time, disfavored populations primarily in the Terai region of the country (IDEA, 2015: 8-9). Thus, these were the, so to speak, fundamental principles that were required to be dealt with in the new constitution that the forthcoming Constituent Assembly was anticipated to draft.

Following the adoption of the interim constitution, 601 members of the Constituent Assembly were elected in April 2008 (IDEA, 2015: 9); or to be completely accurate, 575 member were elected by the Nepalese population, whereas the remaining 21 members were nominated by the Council of Ministers (IDEA, 2015). The election turned out to be a success for the former Maoist insurgents, now transformed into a political party - Communist Party of Nepal (Maoists) - who managed to secure 220 of the 575 seats. The Nepali Congress who had anticipated a victory, came second with 110 seats, closely followed by the Communist Party of Nepal Unified Marxist Leninist with 103 seats. As far as regional parties are concerned, the Madhes Janadhiar Forum secured 52 seats and the Terai Madhes Loktrantik Party won 20 seats (European Union Election Observation Mission, 2008: 38-40).

As stipulated in the rules of procedure for the Constituent Assembly, a number of procedural committees were established for purposes of assisting the members of the Constituent Assembly to draft the constitution (Constituent Assembly Rules of Procedure, 2065, Article 67, 2008). Two of these committees were, above all, installed to facilitate the participation of the Nepalese population in the drafting process. These committees were the Committee on Citizens and the Committee on the Collection and Coordination of Public Opinion. It is worth lingering a bit on the specific tasks of these two committees, as this will help us understand the extent of public participation, and the extent of influence granted to the general public, as envisioned by the members of the Constituent Assembly.

When it comes to the Committee on Citizens, its members were to, among other things; establish channels for the citizenry to be able to access the Constituent Assembly; provide an information system so that citizens could learn about the Constituent Assembly's work; and inform citizens on the process of participation in the formulation of the constitution. If we, just briefly, return to the four factors that were elaborated earlier for purposes of evaluating the extent of public participation in any given constitution-building process, and recall the second factor that dealt with forms of communication, it is quite clear that the main purpose of the Committee on Citizens was to keep the Nepalese population informed about the on goings of the process rather than to provide them avenues for conveying constitutional submissions to the drafters in the Constituent Assembly (Constituent Assembly Rules of Procedure, 2065, Article 67, 2008). When it comes to the Committee on the Collection and Coordination of Public Opinion, however, its tasks reveal that the forms of communication also allowed for the Nepalese populace to provide the members of the Constituent Assembly with constitutional submissions. The committee's task was, among other things, to; disseminate the draft constitution through various media in order 
to collect public opinion and suggestions; to organize public hearings on the draft; and to prepare a report on the suggestions, to be forwarded to the Constituent Assembly (Constituent Assembly Rules of Procedure, 2065, Article 67, 2008). Hence, as far as forms of communication are concerned; the Nepalese constitution-building process of 2008-2012 was an exercise in a two-way model of communication; a dialogue between the members of the committee and the population. Adding to this, it should also be mentioned that Nepalese NGOs and CSOs were essential in facilitating interactions between the citizenry and the committee; organizing workshops, seminars, lectures, etc. that involved the entire population without leaving certain groups out of the participatory process (Khanal, 2014: 15). Hence, the constitution-building process was inclusive in the sense that all groups and parties who wanted to participate, were allowed to do so - no one was banned. This relates to the third factor for evaluating how participatory a constitution-building has been, as mentioned earlier.

All of this would, at first glance, indicate that the general public in Nepal were granted a considerable degree of influence as regards the content of the constitution. And, yes, they were allowed to present their constitutional submission to the members of the Committee on the Collection and Coordination of Public Opinion who were then to forward these to the Constituent Assembly in its entirety. This is true. However, nothing in the Constituent Assembly's rules of procedure indicate that the members of the assembly were obliged to actually include these suggestion in the draft. To put it clearly, the rules of procedure made the participation of the people mandatory, but did not make it compulsory to include what they actually conveyed via their "participation" into the draft. In terms of extent of influence granted to the Nepalese, it can hence be concluded that even though great measures were taken in order to facilitate their participation; it would not necessarily have an effect on the content of the document. Interestingly, and this is where the role of political elites from opposing factions comes into play, a final draft was never even produced because elites from the main political parties in the Constituent Assembly could not reach agreement concerning the fundamental principles outlined in the interim constitution, particularly in regards to the question of federalism and how many federal states the republic was to settle on (Khanal, 2014; IDEA, 2015). After having conducted interviews with approximately 35 individuals involved in the constitution-building process, International IDEA concludes that one of the main challenges of the Constituent Assembly to produce a final draft was the lack of effort among political elites to build consensus with each other; that positions on certain values appeared to be deadlocked; and that compromises appeared to be out of reach (IDEA, 2015: 15). Furthermore, there were no mechanisms for breaking deadlocks in the working procedures of the assembly; no institutional mechanisms for encouraging compromise; nor did all of the negotiations even take place within the formal meetings of the Constituent Assembly but rather outside of it and on an ad-hoc basis (IDEA, 2015: 15). Relating this circumstance to the earlier theoretical discussion, and the thoughts of Rustow (1970) and Diamond (Diamond et al. 2014), it could therefore be argued that the Nepalese transformation to a republic, a federal state, and a democracy failed, in part, because major stakeholders could not consensually agree on the political rules of the game that would stipulate the parameters of "living and doing" politics in post-conflict Nepal, rather than due to a lack of public participation in the process. Taking the ideas of Rustow and Diamond a step further, another possible explanation for the political elite's inability to reach consensus on the outstanding issues that would have given the country a new constitution, could simply be that some of them believed that status quo, after all, would benefit their own interests more; i.e., that a new constitutional order would endanger their positions of power, in turn making it irrational for them to find common ground for purposes of producing a new constitutional draft.

If we were to relate the findings of the 2008-2012 Nepalese constitution-building process to the overarching purpose of this article, two general conclusion can be made. The first is that avenues for the public to participate in the process were plenty and well planned, though as far as participation translating into actual influence is concerned, the process was not successful since the members of the Constituent Assembly were not obliged to draft the constitution on the basis of the suggestions they received from the public. The question, however, is if this would even had mattered in light of the second conclusion. The second conclusion is that, due to political elites not being able to compromise and bargain, a four year constitution-building process resulted in utter failure in the sense that a final draft was not even produced. I light of this, it is relevant to explore the 2013-2015 Nepalese constitution-building process in order to understand what was done differently the second time around, as a final draft was an actual outcome of the second constitution-building process. In the next section, the 2013-2015 process is thus the focus of attention.

\section{The Nepalese Constitution-Building Process of 2013-2015}

To be sure, the second constitution-building process in Nepal differed considerably from the first one, especially as regards the two aspects that are at the focus of attention in this article, namely; how public participation fitted into the process, and how political elites compromised on sensitive constitutional issues so that a constitution 
could finally be produced and subsequently promulgated.

Nearly a year and a half after the first Constituent Assembly in Nepal had been dissolved, elections for a second Constituent Assembly were held in November of 2013. Similarly to the elections to the first Constituent Assembly, 575 members were directly elected by the general public, and the remaining seats nominated by the Council of Ministers (IDEA, 2015: 19). This time around, the balance of power in the assembly shifted to the advantage of the Nepali Congress. The party won 196 seats, making it the largest party, followed by Communist Party of Nepal Unified Marxist Leninist who acquired 175 seats. The Communist Party of Nepal (Maoists), who had been victorious in the elections to the first Constituent Assembly, had to settle for a third place with a mere 80 seats this time around. The National Democratic Party Nepal managed to secure 24 seats, hence becoming the fourth largest party in the Constituent Assembly (IDEA, 2015: 19-20).

The rules of procedure for the second Constituent Assembly, just as was the case with its predecessor, established that a number of committees, whose members were drawn from the assembly, would be installed (Constituent Assembly Rules, 2014, Chapter 11). The Civic Relations and Constitution Suggestion Committee was in charge of dealing with the issue of public participation in the process. However, in great contrast to the working procedures of the previous Constituent Assembly, the rules of procedure for the second assembly and for the Civic Relations and Constitution Suggestion Committee did not make it mandatory for the committee to conduct public hearings prior to the drafting of the constitution, but rather to receive submissions and suggestions from the public when a draft had already been prepared (Constituent Assembly Rules, 2014, Chapter 11, Article 68). Relating this to the issue of how participatory the constitution-building process really was, this course of action undeniably impacts an assessment in a negative manner as it says a great deal about the extent of influence granted to participants; their input would not form the basis of the draft, they would rather be allowed to voice opinions on an elite drafted document. This fallacy could have been remedied had it, for example, been stated in the rules of procedure that the members of the assembly had to take into consideration the viewpoints of the general public as they had been conveyed to the previous Constituent Assembly only a couple of years earlier. Such was, for example, the mandate of the Kenyan Committee of Experts, the body in charge of drafting the Kenyan constitution after this country's 2001-2005 constitution-building process failed to result in a final draft, i.e., much like the 2008-2012 constitution-building process in Nepal. The Committee of Experts in Kenya was, thus, required to take into account the viewpoints of the Kenyan populace as they had been expressed in the first round of constitution-building when the country embarked on its second try, four years later (for further details, see Saati, 2015: 150-160). Such a requirement is, however, absent from the rules of procedure of the second Nepalese Constituent Assembly. What is however stipulated in the rules of procedure for the second Constituent Assembly is that a new committee was to be established; the Constitutional Records Study and Determination Committee, the task of which was to review the documents produced by the first assembly and among those documents identify already agreed upon issues as well as disputed issues (Constituent Assembly Rules, 2014, Chapter 11, Article 66). Here, it is again interesting to make a brief comparison to the second Kenyan constitution-building process as the terms of reference for the Committee of Experts there was also to identify contested as well as agreed upon issues from the first process (The Constitution of Kenya Review Act 2008, Article 23 a-c). However, whereas the Committee of Experts in Kenya was obliged to solicit the viewpoints of the Kenyan population when it came to the issues that were identified as contested from the previous process, this was not the mandate of the Constitutional Records Study and Determination Committee in Nepal. In Nepal, agreed upon issues were sent to a Constitutional Drafting Committee to be directly included in the draft, whereas the disputed issues were sent to a Constitutional-Political Dialogue and Consensus Committee, the task of which was to forge consensus among politicians in the Constituent Assembly concerning these very issues, but without involving the population in doing so. Hence, as far as reaching consensus on sensitive and contentious issues, the Nepalese population were kept out of the process entirely; this matter was left to political elites from different political camps to settle behind closed doors.

This approach, i.e., to leave the outstanding issues that had made it impossible for the first Nepalese Constituent Assembly to produce a final draft in 2012, up to the political elites to bargain and compromise behind closed doors, appears to have been a successful tactic for the second Nepalese Constituent Assembly. After months of negotiations in seclusion from the public eye, Nepalese political elites from the four major parties were able to reach agreement on those very issues that had paralyzed the previous constitution-building process, and a final draft constitution was hence produced - although it ought to be mentioned that discussions were quite harsh even though they were conducted in seclusion. In fact, the deadline for finalizing a constitution by January 2015 was missed due to political elites not being able to reach agreement within the timeframe of the Constituent Assembly's mandate and the final version of the draft was not finished until the end of June that same year 
(Democracy Reporting International, 2016: 9; IDEA, 2015: 21-23). Actually, during the impasse, the country was struck by two devastating earthquakes - the first on April $25^{\text {th }}$ and the second on May $12^{\text {th }}$ - that led to the loss of thousands of lives as well as considerable physical damage to infrastructure in the capital of Kathmandu and nearby locations (BBC, 2015). In the midst of the chaos of these events - and perhaps, in part, as a consequence thereof - political elites managed to show leadership and eventually agree on a 16-point agreement that would push the constitution-building process back on track (IDEA, 2015: 22).

In terms of the issue of sequencing public participation into the constitution-building process to stages when it might be more conducive, the second Nepalese process offers interesting insights that might very well be a consequence of lessons learned from the process of 2008-2012. The outline for the different phases of the constitution-building process this time around, implied public participation at a later stage; namely after political elites had managed to break the deadlock on the most sensitive issues. When the draft was finally completed, the Nepalese public were invited into the process. It should however be duly noted, that the second try at constitution-building in Nepal clearly premiered political elite bargaining, compromise and logrolling instead of public participation. As far as public participation is concerned, and most certainly if one understands participation as something that ought to entail influence over decisions being made, the 2013-2015 constitution-building process was indeed even less participatory than the 2008-2012 process. This time around, as noted above, the Nepalese were not consulted prior to drafting at all, and as far as their input on the draft is concerned, a mere 15 days was set aside for their feedback (Democracy Reporting International, 2016: 9). Though the government announced two public holidays to encourage the Nepalese to make the most of the few days allotted for their involvement in the process, and measures were taken to make sure that the feedback collection was carried out throughout the whole of the country (IDEA, 2015: 25), the 15 day timespan raises doubt as to the extent people were actually able to participate. Questions can be raised as to whether or not most people even felt that they had enough time to read through the whole draft during such a short time span; something that would be a prerequisite in order to be able to provide informed feedback. Beside the fact that the timeframe for feedback was extremely short, another issue also raises doubt as to the extent of influence allowed to the public; namely that nothing in the rules of procedure for the second Constituent Assembly indicate that it was mandatory for the members of this body to include the feedback given and integrate it into a revised draft prior to adopting it (Constituent Assembly Rules, 2014). On the matter of adoption, however, the second constitution-building process must be considered a success; in September of 2015, with overwhelming majority, the Constituent Assembly managed to agree on adopting a new constitution for Nepal (Democracy Reporting International, 2016: 9).

\section{Conclusions}

Public participation in constitution-building during times of transition, from war to peace or from authoritarian to democratic rule, appears to be a trend that is here to stay. The way that international organizations are emphasizing this fast evolving norm indicates that we are likely to see an increasing amount of cases of participatory constitution-building in the future. Because of this, it is important that scholars analyze past empirical cases of participatory constitution-building processes; that we attempt to relate different process related choices during these to specific outcomes, and that we attempt to learn valuable lessons that can be useful for future cases that set out to carry out participatory constitution-building processes of their own, following war or authoritarian rule. As far as these ambitions are concerned, the two Nepalese constitution-building processes that have been the focus of attention in this article provide insights that actually build on, and verify, previous research. A recent study (Saati, 2017b) has shown that when it comes to the issue of how to sequence public participation and political elite negotiations in the context of constitution-building, there are other empirical cases that have also opted for the same sequencing pattern as the 2013-2015 Nepalese constitution-building process. That is, to employ a two-pronged set-up in which the first phase is strictly limited to political elite negotiations and bargaining, whereas the second phase is open to the public to participate. The South African constitution-building process that resulted in the adoption of the 1996 constitution, and the Tunisian process that resulted in the promulgation of the 2014 constitution, both followed this set-up, and have both been heralded for i) involving their respective citizenries, and ii) being able to produce constitutions agreed upon, and respected by, all major political parties (Saati 2017b, Ebrahim \& Miller, 2010; Filali-Ansary, 2014; The Carter Center, 2014). Perhaps two-pronged constitution-building processes that follow this specific logic provide some form of baseline template that post-conflict states can consider when they set out to write new constitutions? Of course, this is not to say that there is one single blueprint; a "one-size fits all" model, which is suitable for all cases to adopt regardless of their individual circumstance. Still, something resembling a pattern can be detected; something that indicates that the only answer when it comes to constitution-building during times of transition, is 
not merely to "open the process to the general public to make their voices heard", but to strike a balance between allowing people to participate and experience a sense of ownership over the constitutional draft, but to also allow political elites to compromise and reach agreements over sensitive constitutional issues that must be dealt with, in that given context. After all, it ought to be remembered that in Nepal, as in most cases, the Constituent Assembly was directly elected by the people which means that even during those phases that the public were not allowed to engage in closed negotiations, these discussion took place between politicians that the people had elected; hence they were participating, but through their chosen representatives.

The finding that is observed in the 2013-2015 Nepalese process, which finds echo in the Tunisian and the South African constitution-building processes concerning two-pronged set-ups does, nevertheless, affect how we think about and analyze "participation" in the context of constitution-building. When major decision relating to the content of the constitution have already been decided by political elites, one might wonder if it is fair to label the inclusion of the public as "participation". Participation in what, exactly, other than in the act of participation? But maybe participation does not need to entail influence over decision being made; perhaps the most important thing is that the public, the Nepalese in this case, are offered an opportunity to voice their opinions even if these are not mirrored in the final draft? However, is it then correct to refer to their engagement as "participation", or should we rather refer to it as "consultation"; a mere conveying of opinions, which the constitution-building body in charge of drafting is free to consider or not to consider? One might think that these are superfluous questions that concern the nitty-gritty issues of semantics. I argue that they are actually not, and that using this term inaccurately can potentially even be harmful. When it is stated that the public, be they the Nepalese people, the Tunisian public, the South Africans or any other population, are going to be allowed to "participate" in the making of their constitution, this invariably gives rise to certain expectations among the populace; expectations that they, in their capacity as citizens, will be allowed to exert influence on the content of the document. If these expectations are not met, and if the public feel that they have been deceived and mislead, something that could have had the potential to benefit the constitution-building process by increasing its legitimacy in the eyes of the public, may have the direct opposite effect, leading to a loss of legitimacy. In terms of strengthening and consolidating democracy, which is the long-term objective of constitution-building processes of today, such expectations transformed into frustration can very well have de-stabilizing effects that harm democratization. Hence, what is really meant by "participation" should be conveyed to the public at the outset of the process to minimize the risk of disappointment, increase the prospect of legitimacy and in the long run, facilitate the consolidation of democracy.

\section{Acknowledgements}

I gratefully acknowledge the funding provided by the Swedish Research Council (grant no. 2016-00378) in order to conduct this research.

\section{References}

Arnstein, S. R. (1969). A Ladder of Citizen Participation. Journal of the American Institute of Planners, 35(4), 216-224. https://doi.org/10.1080/01944366908977225

Banks, A. M. (2007). Challenging Political Boundaries in Post-Conflict States. Faculty Publication, Paper 5. William and Mary Law School.

Banks. A. M. (2008). Extending Participation in Constitution Making: Challenges and Opportunities. William and Mary Law Review, 49(4), 1043-1069.

BBC. (2015). Nepal earthquakes: Devastation in maps and images. Retrieved from http://www.bbc.co.uk/news/world-asia-32479909

Benomar, J. (2003). Constitution Making and Peace Building: Lessons Learned from the Constitution Making Processes of Post-Conflict Countries. United Nations Development Program.

Cheeseman, N., \& Tendi, B. (2010). Power-sharing in comparative perspective: the dynamics of 'unity government' in Kenya and Zimbabwe. Journal of Modern African Studies, 48(2), 203-229. https://doi.org/10.1017/S0022278X10000224

Constituent Assembly Rules of Procedure 2065. (2008).

Constituent Assembly Rules, 2014. (2014). Retrieved from http://d6.constitutionnet.org/sites/default/files/nepal-constituent_assembly_rules_2014.pdf 
Democracy Reporting International. (2016). Case Studies of Constitutional Reform Processes in Transition $\begin{array}{lllll}\text { Countries. } & \text { Briefing } & \text { Paper no. } & \text { Retrieved } & \text { from }\end{array}$ http://democracy-reporting.org/wp-content/uploads/2016/11/DRI-Briefing-Paper-no-73-Nov-2016.pdf

Diamond, L., Fukuyama, F., Horowitz, D. L., \& Plattner, M. F. (2014). Reconsidering the Transition Paradigm. Journal of Democracy, 25(1), 86-100. https://doi.org/10.1353/jod.2014.0018

Ebrahim, H., \& Miller, L. E. (2010). Creating the Birth Certificate of a New South Africa: Constitution Making after Apartheid. In L. E. Miller, \& L. Aucoin (Eds.), Framing the State in Times of Transition: Case Studies in Constitution Making (pp. 111-157). Washington D.C: United States Institute of Peace.

Elster, J. (1995). Forces and Mechanisms of the Constitution-Making Process. Duke Law Journal, 45(364), 38889. https://doi.org/10.2307/1372906

European Union Election Observation Mission. (2008). Nepal, Final Report, Constituent Assembly Election 10 April 2008. Retrieved from http://www.eods.eu/library/FR\%20NEPAL\%2009.2008_en.pdf

Filali-Ansary, A. (2015). Building Consensus in Post-Revolutionary Tunisia. Tunisia-Live Net. Retrieved from http://www.tunisia-live.net/2015/03/03/building-consensus-in-post-revolutionary-tunisia/

Fox, D. T., Gallón-Giraldo, G., \& Stetson, A. (2010). Lessons of the Colombian Constitutional Reform of 1991: Towards the Securing of Peace and Reconciliation? In L. E. Miller, \& L. Aucoin (Eds.), Framing the State in Times of Transition: Case Studies in Constitution Making (pp. 467-482). Washington D.C: United States Institute of Peace.

Ghai, Y., \& Galli, G. (2006). Constitution Building Processes and Democratization. International Institute for Democracy and Electoral Assistance: Stockholm.

Hart, V. (2003). Democratic Constitution Making. United States Institute of Peace. Retrieved from http://www.usip.org/files/resources/sr107.pdf

Hart, V. (2010). Constitution Making and the Right to take Part in a Public Affair. In L. E. Miller, \& L. Aucoin (Eds.), Framing the State in Times of Transition: Case Studies in Constitution Making (pp. 20-56). Washington D.C: United States Institute of Peace.

IDEA. (2015). Nepal's Constitution Building Process: 2006-2015 - Progress, Challenges and Contributions of International Community. International Institute for Democracy and Electoral Assistance: Stockholm.

Khanal, K. (2014). The Participatory Constitution Making Process in Nepal: An Assessment of the CA Process (2008-2012). In B. Karki, \& R. Edrisinha (Eds.), Participatory Constitution Making in Nepal: Issues of Process and Substance (pp. 1-44). United Nations Development Program.

Landau, D. (2012). Constitution Making Gone Wrong. Alabama Law Review, 64(5), 923-980. https://doi.org/10.2139/ssrn.2011440

Moehler, D. (2008). Distrusting Democrats: outcomes of participatory constitution making. The University of Michigan Press: Ann Arbor. https://doi.org/10.3998/mpub.203954

Pateman, C. (1970). Participation and Democratic Theory. Cambridge: Cambridge University Press. https://doi.org/10.1017/CBO9780511720444

Rustow, D. A. (1970). Transitions to Democracy: Toward a Dynamic Model. Comparative Politics, 2(3), 337-363. https://doi.org/10.2307/421307

Saati, A. (2015). The Participation Myth: Outcomes of participatory constitution-building processes on democracy. (Dissertation) Print \& Media. Umeå University.

Saati, A. (2016). Different Types of Participation in Constitution Making Processes: Towards a Conceptualization, Southern African Journal of Policy and Development, 2(2), 18-28.

Saati, A. (2017a). Participatory Constitution-Making as a Transnational Legal Norm: Why Does It "Stick" in Some Contexts and Not in Others? UC Irvine Journal of International, Transnational and Comparative Law, 2, 113-136.

Saati, A. (2017b). Constitution-Building Bodies and the Sequencing of Public Participation - A Comparison of Seven Empirical Cases, Journal of Politics and Law, 10(3), 13-25. https://doi.org/10.5539/jpl.v10n3p13

Samuels, K. (2006). Post-Conflict Peace-Building and Constitution-Making. Chicago Journal of International Law, 6(2), 1-20. 
Samuels, K. (2009). Postwar constitution building: Opportunities and challenges. In R. Paris, \& T. Sisk (Eds.), The Dilemmas of Statebuilding: Confronting the Contradictions of Postwar Peace Operations (pp. 173-195). New York: Routledge.

Shakya, P. M. (2014). Review of the Past Constitution-Making Process and Lessons for the Future. In B. Karki, \& R. Edrisinha (Eds.), Participatory Constitution Making in Nepal: Issues of Process and Substance (pp. 89-106). United Nations Development Program.

The Carter Center. (2014). The Constitution-Making Process in Tunisia: Final Report. The Carter Center. Atlanta.

The Constitution of Kenya Review Act 2008.

Tripp, A. M. (2010). The Politics of Constitution Making in Uganda. In L. E. Miller, \& L. Aucoin (Eds.), Framing the State in Times of Transition: Case Studies in Constitution Making (pp. 158-175). Washington D.C: United States Institute of Peace.

Widner, J. (2008). Constitution Writing in Post-Conflict Settings: An Overview. William \& Mary Law Review, 49(4), 1513-1537.

\section{Copyrights}

Copyright for this article is retained by the author(s), with first publication rights granted to the journal.

This is an open-access article distributed under the terms and conditions of the Creative Commons Attribution license (http://creativecommons.org/licenses/by/4.0/). 